\title{
System productivity and profitability of sweet corn - chickpea cropping system as influenced by land configuration, plant population and integrated nitrogen management
}

\author{
V. G. Nagdeote ${ }^{1}$, Mangala Ghanbahadur ${ }^{2}$, A.R. Mhaske* and R.M. Ghodpage ${ }^{3}$ \\ Department of Agricultural Engineering, College of Agriculture, NAGPUR (M.S.) INDIA \\ (Email : mhaskear@gmail.com)
}

\begin{abstract}
An experiment was conducted on vertisol at the farm of University Department of Agronomy, Dr. PDKV., Akola during Kharif and Rabi season of 2010-11 and 2011-12, to study the system productivity and profitability of sweet corn - chickpea cropping system as influenced by land configuration, plant population and integrated nitrogen management. Sweet corn yields were significantly higher in ridges and furrow with plant population of 55556 plants ha ${ }^{-1}$ and $100 \% \mathrm{~N}$ through inorganic fertilizer. However, sowing of sweet corn on ridges and furrow with plant population of 55556 plants ha- $\left(60 \times 30 \mathrm{~cm}^{2}\right)$ along with substitution of 50 per cent $\mathrm{N}$ through organic manure (vermicompost) to sweet corn crop exhibited remarkable residual effect on yield and GMR, NMR, B:C ratio of chickpea. This indicates benefits of vermicompost on subsidizing season chickpea than prevailing sweet corn. The system equivalent yield, GMR, NMR, B:C ratio of sweet corn - chickpea cropping sequence was maximum with sowing of sweet corn on ridges and furrow with plant population of 55556 plants per hectare $\left(60 \times 30 \mathrm{~cm}^{2}\right)$ along with application of 100 per cent $\mathrm{N}$ through inorganic fertilizers to sweet corn. System production efficiency and economic efficiency were also higher with these treatments.
\end{abstract}

Key Words : Cropping sequence, Profitability, Sweet corn equivalent yield, Production efficiency

View Point Article : Nagdeote, V.G., Ghanbahadur, Mangala, Mhaske, A.R. and Ghodpage, R.M. (2018).System productivity and profitability of sweet corn - chickpea cropping system as influenced by land configuration, plant population and integrated nitrogen management. Internat. J. agric. Sci., 14 (1) : 70-75, DOI: 10.15740/HAS/IJAS/14.1/70-75.

Article History : Received : 22.05.2017; Revised : 09.11.2017; Accepted : 22.11.2017

\footnotetext{
* Author for correspondence:

${ }^{1}$ Department of Agronomy, College of Agriculture, NAGPUR (M.S.) INDIA

${ }^{2}$ All India Co-ordinated Research Project on Farming Systems Research, Dr. P.D.K.V., AKOLA (M.S.) INDIA

${ }^{3}$ Department of Soil Science and Agricultural Chemistry, College of Agriculture, NAGPUR (M.S.) INDIA
} 